\title{
Utilization of Palm Oil Shells (Elaeis Guineenses Jacq) as Particle Board Raw Material
}

\author{
Maya Dewi Dyah Maharani ${ }^{1}$, Istianto Budhi Rahadja ${ }^{2}$, Yudi Dermawan ${ }^{3}$, Anasrul $^{4}$, Lydia Anggraini ${ }^{5}$ \\ ${ }^{1}$ Environmental engineering, University of Sahid, Jl. Prof. DR Soepomo, Menteng Dalam, Jakarta 12870, Indonesia \\ ${ }^{2,3,4}$ Plantation processing technology, palm oil Polytechnic Citra Widya Edukasi, Jl. Gapura 8, Rawa Banteng, Setu, Cibitung, Bekasi, \\ Jawa Barat, 71520, Indonesia
}

${ }^{5}$ Mechanical Engineering, University of President, Jl. Ki Hajar Dewantara, Cikarang, Bekasi, Jawa Barat 17550, Indonesia

\begin{abstract}
Particle board is a commodity in high demand in Indonesia. However, because wood is the main raw material involved in particle board production, this high demand poses a great threat to forest ecosystems. Therefore, palm oil shells have been adopted as a substitute for wood by the government, as a countermeasure to help protect forests. Particleboard is made by combining wood particles or similar powders with a polyester resin adhesive. Therefore, the aim of this study was to examine the effect of palm oil shell particle size on the quality of the particleboard produced. The manufacturing process consisted of raw material preparation, printing and testing. The raw materials were palm oil shells and polyester resin adhesives, while the printing process involved combining the 50\% polyester resin adhesives with mesh shell particles with sizes of 4, 12, and 30. Conventional methods of testing were used to analyze the particle board quality, by assessing how much potential energy each material could receive before breaking. The results showed that the optimum quality of particle board was made using a mesh size of 30, which was able to receive 1,764 joules of potential energy without breaking.
\end{abstract}

Keywords: PalmShell, Particleboard, Polyester Resin, ParticleSize, Conventional-Testing

\section{Introduction}

Oil palm trees in Indonesia can be grown both in mineral lands and peatlands (Andreas Wahyu Krisdiarto, Lilik Sutiarso, 2016). Oil palm trees are located in rural areas, spread mostly on Sumatera, Kalimantan (Borneo) and Papua islands (Roni Maryana, 2015). Palm trees are processed in factories to produce Crude Palm Oil (CPO) and Palm Kernel Oil (PKO), which are the primary materials used in the palm oil industry (Pardamean, 2011). While Waste Palm Kernel Shells and Empty Palm Oil Bunches have the potential as liquid smoke raw materials (L Ni mah, M F Setiawan, and S. P. Prabowo, 2019), and particle board. Nut and kernel recovery stations are the sections of palm oil mills where the shell and the kernel are separated. By processing 10 tons of Empty Palm Oil Bunches, the products consist approximately of $1.2 \%$ oil palm shells and $1.4 \%$ fiber. The potential for beneficial palm oil waste to encourage the palm oil industry to support sustainable development. The palm oil industry in Indonesia has the potential to support sustainable development, as seen from the social dimension index 54.50\% (quite sustainable) (Lili Dahliani and Maya Dewi Dyah Maharani, 2018).

In Indonesia, the demand for particle board is increasing and the materials used to produce these particle boards are mostly obtained from wood removed from forest areas. This can have a negative effect on the environment.Palm oil shells can be processed and made into composite boards or particleboard, which are produced by gluing together particles of wood or fine powder using resin adhesive (Tsoumis, 1991). The raw material used for manufacturing boards can vary because there are not strict requirements in place for its production. This means that oil palm shells can be easily utilized as a raw material for particle board manufacturing. Furthermore, palm oil shell solid waste can also be used in roof building as a way of reducing heat loss (RahardjaIstanto Budhi,2018 ).In addition to oil palm shells, Oil Palm Empty Fruit Bunch, and Oil Palm Trunkalso have the potential to become particle boards (Wahida A. F and Ghazi Faisal Najmuldeen. 2015;Mirna Rahmah Lubis et. al., 2018; Nadiah Binti Jumhuri, 2016).

Adhesives will continuously play an important role in the development and growth of the forest products industry (Frihart CR. 2015). The use of adhesives that impact carcinogens continues to be developed, for the safety and health of humans in the development of the particle board industry. Formaldehyde emission at or below the level of natural wood shall serve as current benchmark for the evaluation of novel formaldehyde free alternatives. This is important, because formaldehyde emissions are potentially as a carcinogens (Pia Solta et. al., 2019). The purpose of this study were: (i) Investigating the size of oil palm shells (mesh 4, mesh 12, and mesh 30) for producing particle board quality; (ii) Determine the feasibility of mechanical and physical properties of resin use in the manufacture of particle boards

\section{Materials and Methods}

\subsection{Material Particles Preparations}

Palm oil shells are a form of solid waste that is produced by processing FFB into CPO and PKO. Specifically, palm shells are obtained by separating the kernels, and are characterized by a grayish black colour, an irregular shape, and a high degree of hardness. Provide the shell of oil palm, then formed a small shell using a crusher tool. Take out the palm shell with the selected mesh. The unvoted part is set aside. Selected palm shells are put in containers and ready to be put together with additives

Volume 10 Issue 3, March 2021 


\subsection{Making Shell Parcitel Board Molds}

Provide iron plate with dimensions ( $35 \times 35$ x 0.30$)$ cubic $\mathrm{cm}$. It is then cut into $(25 \times 25)$ square $\mathrm{cm}$ sizes as the base of the particle mold. On all sides the edges are hollowed out as upper and lower base fasteners. Cut back the iron plate to form a square as part of a mold with a height of $1 \mathrm{~cm}$ from the base of the initial mold. Then welded so that it forms a square mold with a size $(20 \times 20 \times 1)$ cubic $\mathrm{cm}$. Tidy the sides of the welded parts with grinding. Particle board mold ready to use

\subsection{Manufacture of Parcitel Shell Boards (resin and Shell mixing)}

This research used polyester resin, which is the most widely used resin in the production of particle boards

\subsection{Particleboard Evaluation - Hardness Testing}

To evaluate the quality of the particle board material are using shore D Durometer Testingmethod, and test hardness. The approach of hardness tests by dropping iron balls with varying heights until there is a change.

\section{Results and Discussion}

The results of study assessed is the effects of different shell sizes - mesh 4, mesh 12, and mesh 30 - on the quality of the particle boards produced. The quality of the particle board is carried out through a hardness test, which is to give a direct load to the material by dropping an iron ball 225 grams from varying heights. This is done repeatedly until the material undergoes characteristic changes. Table 1 showed hardness test results.

Table 1: Conventional Method Testing Data

\begin{tabular}{|c|c|c|c|c|c|c|c|}
\hline $\begin{array}{c}\begin{array}{c}\text { Particle Size } \\
\text { (mesh) }\end{array} \\
\end{array}$ & \begin{tabular}{|c|} 
Resin \\
Composition (\%) \\
\end{tabular} & \begin{tabular}{|c|}
$\begin{array}{c}\text { Dimension } \\
(\mathrm{cm})\end{array}$ \\
\end{tabular} & Height $(\mathrm{cm})$ & Time (s) & Indication & $\begin{array}{c}\text { Iron Ball } \\
\text { Diameter }(\mathrm{mm}) \\
\end{array}$ & $\begin{array}{l}\text { Iron Ball } \\
\text { Mass (gr) } \\
\end{array}$ \\
\hline \multirow{9}{*}{4} & \multirow{9}{*}{50} & \multirow{9}{*}{$5 \times 5 \times 1$} & 35 & 8,8 & No breaking & 4,1 & \multirow{9}{*}{225} \\
\hline & & & 40 & 9 & No breaking & 4,1 & \\
\hline & & & 45 & 9,7 & No breaking & 4,3 & \\
\hline & & & 50 & 10 & No breaking & 4,3 & \\
\hline & & & 55 & 10,5 & No breaking & 4,4 & \\
\hline & & & 60 & 11 & Broken & 4,4 & \\
\hline & & & 60 & 11,5 & No breaking & 4,4 & \\
\hline & & & 65 & 11,1 & Broken & 4,6 & \\
\hline & & & 70 & 11,4 & Broken & 4,6 & \\
\hline \multirow{8}{*}{12} & \multirow{8}{*}{50} & \multirow{8}{*}{$5 \times 5 \times 1$} & 35 & 8,7 & No breaking & 4,1 & \multirow{8}{*}{225} \\
\hline & & & 40 & 8,9 & No breaking & 4,1 & \\
\hline & & & 45 & 9,6 & No breaking & 4,3 & \\
\hline & & & 50 & 10,2 & No breaking & 4,3 & \\
\hline & & & 55 & 10,7 & Broken & 4,4 & \\
\hline & & & 55 & 10,9 & Broken & 4,4 & \\
\hline & & & 55 & 10,6 & No breaking & 4,4 & \\
\hline & & & 60 & 11,5 & Broken & 4,4 & \\
\hline \multirow{10}{*}{30} & \multirow{10}{*}{50} & \multirow{10}{*}{$5 \times 5 \times 1$} & 45 & 9,4 & No breaking & 4,3 & \multirow{10}{*}{225} \\
\hline & & & 50 & 9,9 & No breaking & 4,3 & \\
\hline & & & 55 & 10,7 & No breaking & 4,4 & \\
\hline & & & 60 & 11 & No breaking & 4,4 & \\
\hline & & & 65 & 11,2 & No breaking & 4,6 & \\
\hline & & & 70 & 11,4 & No breaking & 4,6 & \\
\hline & & & 75 & 11,6 & No breaking & 4,6 & \\
\hline & & & 80 & 11,8 & Broken & 4,6 & \\
\hline & & & 80 & 11,7 & Broken & 4,6 & \\
\hline & & & 80 & 11,8 & Broken & 4,6 & \\
\hline
\end{tabular}

Based on the data above, the amount of potential energy received by the test material can be measured using the equation $\mathrm{Ep}=\mathrm{m} \times \mathrm{g} \times \mathrm{h}$. The data from the hardness test can be seen in Table 2 .

Table 2: Data from hardness testing results

\begin{tabular}{|c|c|c|c|}
\hline $\begin{array}{c}\text { Particle Size } \\
(\mathrm{mesh})\end{array}$ & $\begin{array}{c}\text { Height } \\
(\mathrm{Cm})\end{array}$ & $\begin{array}{c}\text { Density } \\
\left(\mathrm{g} / \mathrm{cm}^{3}\right)\end{array}$ & $\begin{array}{c}\text { Potential energy } \\
(\text { Joule })\end{array}$ \\
\hline 4 & 60 & 817,75 & 1,3230 \\
\hline 12 & 55 & 828,75 & 1,2127 \\
\hline 30 & 75 & 878,25 & 1,6537 \\
\hline
\end{tabular}

(Source: Test result data, 2019)
The potential energy received by a mesh size 12 is the smallest, at 1.2127 Joules. This is because the adhesive in the particle board is concentrated in one particular area during the printing process, the adhesive properties easily crystallize, and weaken the particle and adhesive interface.Based on the test results, the potential energy received by mesh shell sizes 4,12 , and 30 is described in the following graphs. Where: $\mathrm{x}$ is potential energy (Joule) and $\mathrm{Y}$ is the shell size (mesh)

\section{Volume 10 Issue 3, March 2021 www.ijsr.net}




\section{International Journal of Science and Research (IJSR)}

ISSN: 2319-7064

SJIF (2019): 7.583

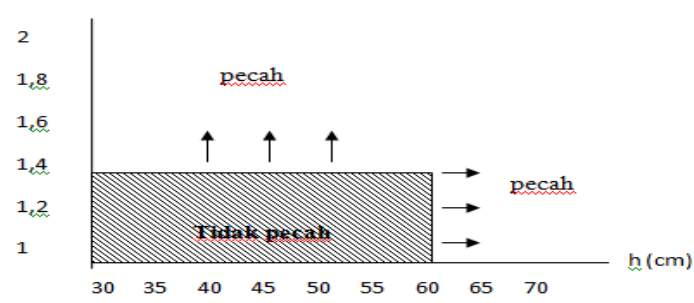

Figure 1: Potential energy relation graph with height for mesh size 4

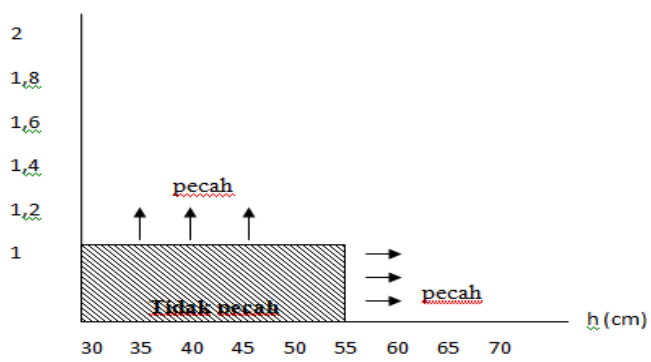

Figure 2: Potential energy relation Graph with height for

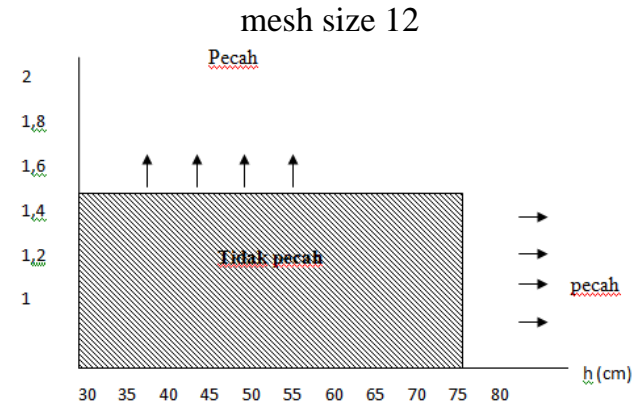

Figure 3: Potential energy relation graph with height for mesh size 30

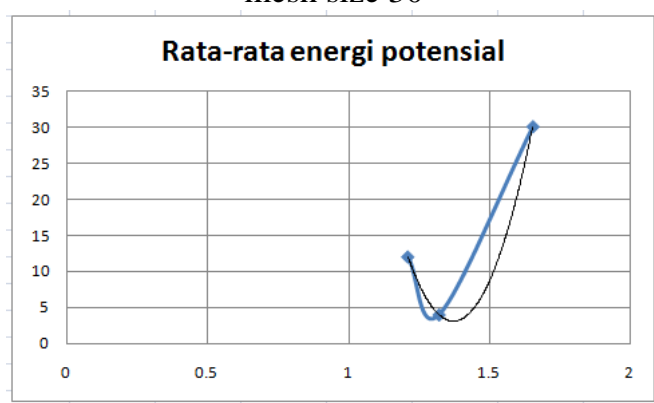

Figure 4: Average potential energy graph

Mesh particle board size 12 after hardness testing can be seen in Figure. 5.

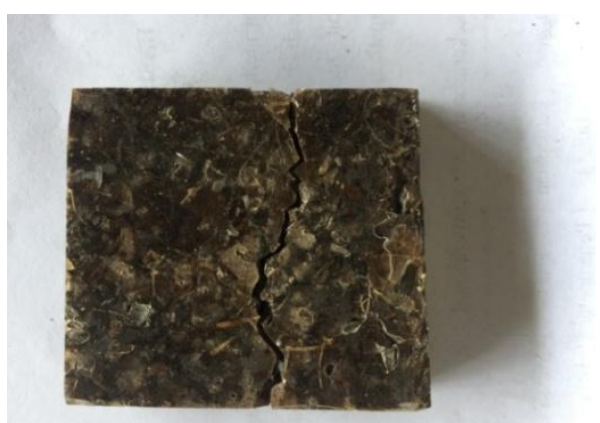

Figure 5: Particle Board Mesh size 12 after testing

Mesh size 4 experienced unfavorable changes due to the higher ratio of adhesive mass to shell particles, which increased the amount of space between the particle board. During the mixing process, particles within the adhesive are difficult to homogenize, the polyester resin becomes unevenly distributed within the cavities. This process results in polyester resin not homogeneously binding particles, instead forming a transparent crystal and producing a poorly formed particle board (Figure 6)

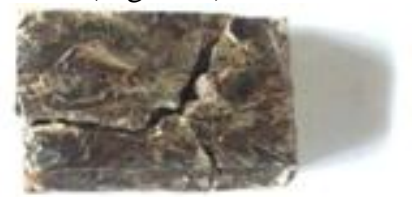

Figure 6: Particle Board mesh size 4 after testing

Mesh size 30 value was the highest, having a smaller particle size, meaning the material strength was more homogeneous. This was because the relationship between the adhesive and the shell particles was mutually supportive, helping to produce a particle board with a good hardness (Figure 7). In general, the higher the density of the raw materials that make up a particle board, the higher the resulting particle board strength (Haygreen and Bowyer, 1989).

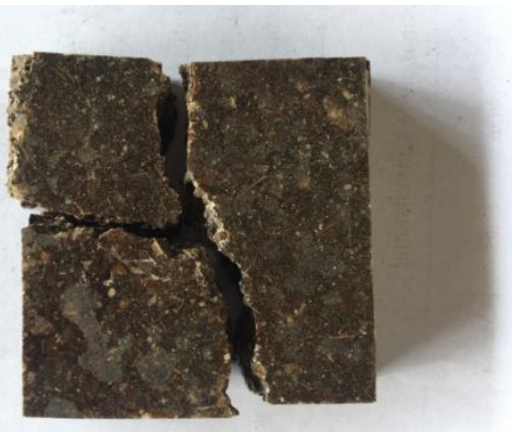

Figure 7: Particle board Mesh size 30 after testing

\subsection{Durometer Testing}

The research results also assessed the effect of different shell sizes (mesh 4, mesh 12, and mesh 30) on the quality of particle boards by using the shore D Durometer $80 \mathrm{HD}$ method (table. 3)

Table 3: Testing Data of Shore D Durometer 80 HD Method

\begin{tabular}{|c|c|c|c|}
\hline $\begin{array}{l}\text { Shell particle } \\
\text { size }(\text { mesh })\end{array}$ & $\begin{array}{c}\text { Resin } \\
\text { Composition }\end{array}$ & $\begin{array}{c}\text { hardness } \\
\text { (HD) }\end{array}$ & $\begin{array}{c}\text { Average Hardness } \\
\text { Value(HD) }\end{array}$ \\
\hline \multirow{5}{*}{4} & \multirow{5}{*}{$50 \%$} & 63 & \multirow{5}{*}{64} \\
\hline & & 65 & \\
\hline & & 63 & \\
\hline & & 60 & \\
\hline & & 68 & \\
\hline \multirow{5}{*}{12} & \multirow{5}{*}{$50 \%$} & 70 & \multirow{5}{*}{72} \\
\hline & & 72 & \\
\hline & & 74 & \\
\hline & & 73 & \\
\hline & & 71 & \\
\hline \multirow{5}{*}{30} & \multirow{5}{*}{$50 \%$} & 84 & \multirow{5}{*}{84} \\
\hline & & 82 & \\
\hline & & 87 & \\
\hline & & 82 & \\
\hline & & 84 & \\
\hline
\end{tabular}

(Source: Test result data)

\section{Volume 10 Issue 3, March 2021 www.ijsr.net}


Based on shore D Durometer 80 method, the average hardness value can be seen in Figure.7

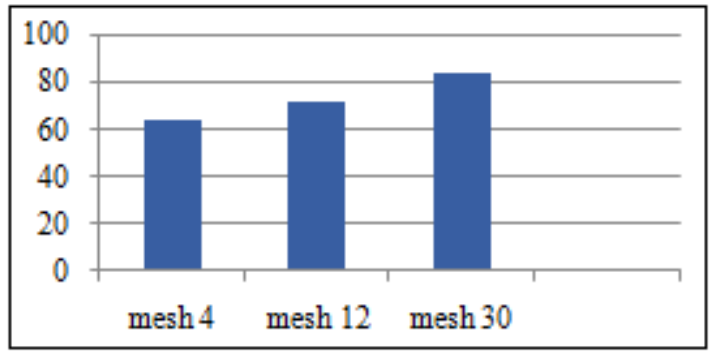

Figure 7: Hardness Value of D Durometer 80

Composite mesh size 4 had the lowest value because had very high crystalline, and the adhesive was concentrated in one particular area causing the particle and adhesive interface to be weakened (figure. 8)

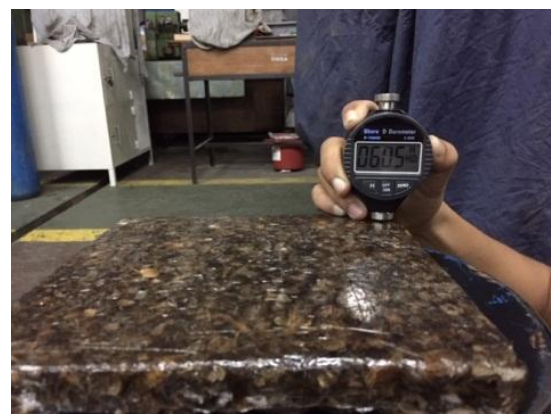

Figure 8: Composite mesh 4

Meanwhile, the particle board composite of mesh size 12 had a value of $72 \mathrm{HD}$. This low value was due to the high ratio of adhesive mass to shell particles, meaning there was a large amount of space between the particles. Furthermore, during the mixing process, particles did not homogenize well within the glue. Therefore, the polyester resin was distributed within cavities in a way that did not allow homogeneous binding with the particles, forming a transparent crystal. Overall, this resulted in a poor particle board. The result can be seen in Figure. 9

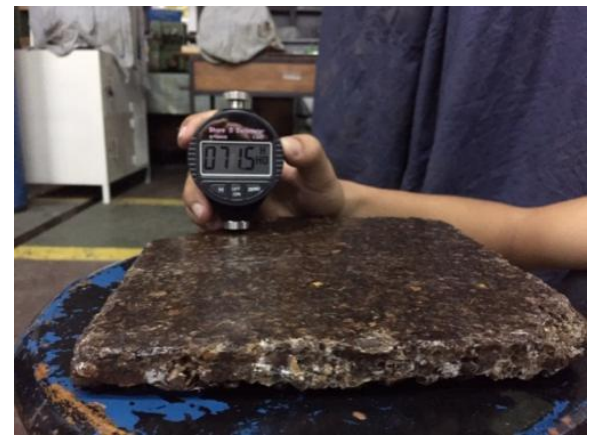

Figure 9: Composite mesh 12

Composite particle board mesh 30 had a value of 84 HD. This was the highest hardness value and meets the D durometer 80 HD standard (PCE,1999; Kent Larson, 2017; James, D. Pampush, et. al., 2011, Chung-Yoo Kim, et. al., 2019). Because the particle size in this mesh was smaller, the material strength was more evenly distributed. This was due to the mutually supportive relationship between the ad- hesive and the shell particles, producing a particle board with a good hardness.

\section{Conclusion}

Palm oil shell has the potential to be used as a raw material for particle board production, by being combined with polyester resin adhesive. The amount of potential energy each mesh size was able to receive without breaking was 1.3230 Joules for mesh size 4, 1.2127 Joules for mesh size 12 and 1.6537 Joules for mesh size 30 . Based on the test results, mesh size 12 had the lowest value because the adhesive was highly concentrated in one area during the printing process. Meanwhile, mesh size material 30 had the most optimum hardness when compared to the other sizes due to the mutually supportive relationship between the adhesive and the palm oil shell particles. The average hardness value of particle board composite mesh sizes 4, 12 and 30 were $64 \mathrm{HD}, 72 \mathrm{HD}$, and $84 \mathrm{HD}$ respectively. The highest hardness value of particle board composite was found in mesh 30, which meets D durometer $80 \mathrm{HD}$ standard. Therefore, this mesh size represents the best size to be used in the production of particle boards.

\section{References}

[1] Andreas Wahyu Krisdiarto, LilikSutiarso. 2016. Study on Oil Palm Fresh Fruit Bunch Bruise in Harvesting and Transportation to Quality. Makara Journal of Technology. Vol. 20, No. http://journal.ui.ac.id/technology/journa 1/article/view/3058

[2] Roni Maryana, 2015, Preparation of dissolving pulp from oil palm empty fruit bunch by prehydrolysis soda-anthraquinone cooking method, http://bptba.lipi.go.id/bptba.

[3] Pardamaen,M.2011.Sukses Membuka Kebun dan Pabrik Kelapa Sawit: Jakarta,Penebar Swadaya

[4] L Ni mah, M F Setiawan, and S. P. Prabowo, 2019, Utilization of Waste Palm Kernel Shells and Empty Palm Oil Bunches as Raw Material Production of Liquid Smoke. International Conference on Sustainable Insfrastructure, doi:10.1088/17551315/366/1/012032),

[5] Lili Dahliani and Maya Dewi Dyah Maharani. 2018. Palm Oil Sustainable Management Using MDS Model from Social Dimension, 5th International Conference on Community Development (AMCA 2018). Advances in Social Science, Education and Humanities Research, volume 231. Atlantis Press. https://www.researchgate.net/publication/327900329 Palm_Oil_Sustainable_Management_Using_MDS_Mo del_from_Social_Dimension)

[6] Tsoumis, G. 1991. Science and Technology Wood. Structure, Properties, Utilization. Van Vonstrand Reinhold Inc. USA. Walker, J.C.F. 1993. Primary Wood Processing Principle

[7] Rahardja, Istianto Budhi, 2018 . Analisis of Heat Tranfer of Fiber Mesocarp af Palm Oil (Elaeis Guineensis Jacq) as Roof Building. Journal of Applied Sciences and Advanced Technology

[8] Wahida A. F and Ghazi Faisal Najmuldeen. 2015. One Layer Experimental Particleboard from Oil Palm

\section{Volume 10 Issue 3, March 2021}


Frond Particles and Empty Fruit Bunch Fibers. International Journal of Engineering Research \& Technology (IJERT)

[9] Mirna RahmahLubis, TeukuMaimun, Jon Kardi, and RifdullahBikriMasra. 2018. Characterizing Particle Board Made of Oil Palm Empty Fruit Bunch Using Central Composite Design. Makara Journal of Science, 22/1 (2018), 17-28 doi: 10.7454/mss.v22i1.6988

[10] Nadiah Binti Jumhuri. 2016. Properties Of Particle Board Made From Treated Oil Palm Trunk Particle, Thesis submitted in fulfillment of the requirements for the degree of Master of Science, UniversitiSains Malaysia)

[11] Frihart CR. 2015. Introduction to special issue, wood adhesive: past, present, and future. For Prod J. 65:4-8.

[12] Pia Solta, Johannes Konnerth, Wolfgang GindlAltmutter, Wolfgang Kantner, Johann Moserc, Roland Mitterd, Hendrikus W.G. van Herwijnena. 2019. Technological performance of formaldehyde-free adhesive alternatives for particleboard industry. International Journal of Adhesion and Adhesives 94:99-131).

[13] Haygreen,J.G dan Bowyer,J.L. 1989. Hasil Hutan dan Kayu. Terjemahan: Hadikusumo,S.A. Gajah Mada University Press, Yogyakarta

[14] PCE. 1999. Durometer / Shore Durometer. https://www.pce-instruments.com/english/measuringinstruments/test-meters/durometer-shore-durometerkat_40047.htm. accessed 8th January 2021).

[15] Kent Larson, 2017. Can You Estimate Modulus From Durometer Hardness for Silicones? Yes, but only roughly $\ldots$ and you must choose your modulus carefully!.Dow

Corning Corporation.https://www.researchgate.net/publication/ 336239577_Can_You_Estimate_Modulus_From_Duro meter_Hardness_for_Silicones_Yes_but_only_roughly _and_you_must_choose_your_modulus_carefully).

[16] James, D. Pampush, Anna, E. Vick, David, J. Daegling, William Scott Mcgraw. 2011. Technical note: Converting durometer data into elastic modulus in biological materials. American Journal of Physical Anthropology. 146:650-653

[17] Chung-Yoo Kim, Jong-Ho Kang, Tae-Sung Park. 2019. Intra-Rater Reliability of the Shore Durometer in the Assessment of Upper Trapezius Muscle Hardness. Research Journal of Pharmacy and Technology. 12(5):2461-2464

Volume 10 Issue 3, March 2021 www.ijsr.net 